\title{
Management of Inclusive School Curriculum in Indonesia
}

\author{
Mudjito.AK ${ }^{\mathrm{a}}$, Sujarwanto ${ }^{\mathrm{b}}$, Muhammad Nurul Ashar \\ Faculty of Education, Surabaya State University, Surabaya, Indonesia
}

\begin{abstract}
Inclusive education in Indonesia has been going on long time. In its development there are still many problems found, one of the main problems is curriculum management. The objectives of this research were to know (1) the problems in implementing the management of inclusive school curriculum in Indonesia, (2) the causes of problems in implementing the management of inclusive school curriculum in Indonesia, and (3) the recommended model of management of the inclusive school curriculum in Indonesia. This research used a literature study which was done through stages consisting of collecting data, data analysis by meta-analysis with qualitative approach, and conclusion drawing. The results showed that there were many problems in implementing the management of inclusive school curriculum in Indonesia, moreover the problems were caused by some factors such as lacks of knowledge and experience, training program, and government support. To cope with those problems, the recommended model for implementing the management of the inclusive school curriculum was the school based- quality improvement management model which was done through stages including planning, organizing, implementing, and monitoring.
\end{abstract}

Keywords: $\quad$ Management, Inclusive School, Curriculum

\section{INTRODUCTION}

Indonesia is a developing country with the huge number of people with disabilities according to the data by the World Health Organization (WHO), there are almost 24 millions of people in Indonesia or 10 percent of Indonesian people known as the disabled (ILO, 2014). So that to ensure every people with disabilities in Indonesia gets education access, the Indonesian government has already implemented inclusive education as the solution. Referring to the Strategic Plan of the Indonesia National Ministry of Education in 2005, it was written that education services for people with disabilities in Indonesia can be done through two educational services provided special schools and inclusive schools, but inclusive schools are more accentuated in Indonesia instead of special schools because of the aspect of accessibility and economical reason (Garnida, 2015: 57). While service in special schools reserves for people with disabilities whose experiences severe disabilities and need special intervention.

The philosophy of Inclusive education is also in line with Indonesia national motto, Unity in Diversity, which means that diversity is not a barrier but an unifier. Moreover, Smith (2015:44) states that inclusive is a commitment to engage students with disabilities in each level of education that they possibly allow (Smith, 2015: 44). While the goal of inclusive education is practically to educate people with disabilities in regular classes together with other people without disabilities through proper support needed, both at school and in the neighborhood (Firdaus, 2010). So in inclusive schools, schools must adapt to the needs of all students, and ready to accept whatever the condition of students are (Garnida,
2015: 56). So it can be concluded that inclusive education is the education system that allows all students, no matter what their conditions are like, to get appropriate education services based on their abilities.

The development of inclusive education in Indonesia has been going on for a long time. Inclusive education in Indonesia started in 1960 in the Bandung City, West Java Province, and after that inclusive education in Indonesia has been growing into a positive trend. Based on data by Indonesia Directorate of Special Education and Services (2013), the number of inclusive schools in Indonesia in 2007 was about 925 schools (from elementary school until senior high school levels) and in 2013 the number of inclusive schools was about 2.100 schools (also ranging from elementary school until senior high school levels). Although the condition showed positive response of inclusive education, but few years after that the trend of inclusive education in Indonesia had decreased. This could be seen or proved from the decline in the ranking presented by UNESCO on the implementation of inclusive education in Indonesia, which only achieved 58 out of 130 countries in 2008, then, it tended to decline again and again year by year. One of the main problems of the implementation of inclusive education in Indonesia derives from the curriculum management.

Based on General Guide of Inclusive Education Implementation in Indonesia (2011), curriculum management is the management process which is concerned with modifying national curriculum based on the disabilities students ability and characters. Moreover, curriculum management is crucial in the implementation of inclusive education, because by an appropriate implemention of curriculum, all of the students, including disabilities students can take 
advantage from learning process, and also develop their potentials optimally (Mara \& Mara, 2012).

Previous research which was done by Tarnoto (2016) in Yogyakarta Province shows that several schools didn't do any modification in curriculum for students with disabilities. 'So that the aims of this research are to know (1) the problems in implementing the management of inclusive school curriculum in Indonesia, (2) the causes of problems in implementing the management of inclusive school curriculum in Indonesia, and (3) the recommended model of management of the inclusive school curriculum in Indonesia.

\section{METHOD}

This research used the literature study method to solve the problems through the collection of discussions which was based on some literature such as books, journals, articles, official reports, and other information resources to be collected in relation to the inclusive education management matters. The literature study in this research was divided into three stages - the data collection, the data analysis, and the conclusion drawing. Research process can be seen in figure 1 as follows:

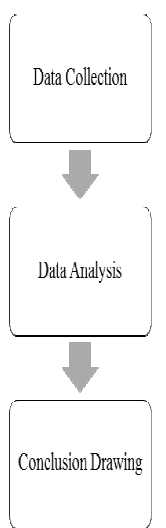

Figure. 1. Research Process

The process of collecting the data was done through selecting the data which had been collected before including various literature sources. The data used were connected to the implementation of the management of the inclusive school teachers either in the form of research or thought. In particular, the data found from any literature sources above needed to be selected to get the best technique that could be used to answer the research questions.

The next process was the data analysis. The data which had been collected needed to be analyzed to find the relevant facts to answer the research questions. The process of the data analysis in this research used meta-analysis by employing inductive descriptive analysis technique. In this case, the data in this research were analyzed until it could find the answers to the research questions, and develop effective model of the management of the inclusive school teacher. The final process of the literature study is drawing the conclusion based on the results of the data analysis.

\section{RESULT AND DISCUSSION}

There have been lots of of researches conducted in terms of inclusive education implementation in Indonesia. But this paper only analyzed ten researches ranging from 2009 until 2016, with the inclusive schools studied were located in seven different provinces in Indonesia. First was the research by Sunardi (2009) who analyzed twelve inclusive schools in Bandung (West Java Province), second Sunanto (2009) who analyzed two inclusive schools in Bandung (West Java Province). Third was Sunardi, Yusuf, Gunarhadi, Priyono, \& Yeager (2011) who investigated 186 inclusive schools in some cities including Palembang (South Sumatra Province), Solo, Wonogiri, Sukoharjo, Karanganyar, and Boyolali (Central Java Province), and Makasar (South Sulawesi Province). Fourth was the research done by Wati (2014) who observed one inclusive school in Aceh Province. Fifth was Issabela, Emosda, $\&$ Suratno who analyzed one inclusive school in Jambi Province. Sixth was Yusuf, Sunardi, Rachman, \& Haryono (2014) who analyzed 51 inclusive elementary schools in Central Java Province. Seventh was Haryono \& Widiastuti (2015) who conducted the research in 591 inclusive schools in Central Java Province. Eight was Zakia (2015) who held research in four elementary schools in Sukoharjo. Next was Rifani (2016) who conducted the research in one inclusive school in Yogyakarta Province And the last was research by Tarnoto (2016) in 18 inclusive schools in Yogyakarta Province.

There were various problems found in relation to the implementation of the management of the inclusive school curriculum in Indonesia as listed or shown in table 1 bellow: 
Table I. Problems In Inclusive School Curriculum Management

\begin{tabular}{|c|c|c|}
\hline No & Research by & Problems \\
\hline 1 & Sunardi (2009) & $\begin{array}{l}\text { Teachers have difficulties } \\
\text { in modifying the } \\
\text { curriculum for disabilities } \\
\text { students, moreover the } \\
\text { curriculum target is quite } \\
\text { same as for regular } \\
\text { students }\end{array}$ \\
\hline 2 & Sunanto (2009) & $\begin{array}{l}\text { The implementation of } \\
\text { curriculum management } \\
\text { mainly done only by } \\
\text { special education teachers } \\
\text { (lack of collaboration } \\
\text { between each school } \\
\text { member) }\end{array}$ \\
\hline 3 & $\begin{array}{c}\text { Sunardi, Yusuf, } \\
\text { Gunarhadi, Priyono, \& } \\
\text { Yeager (2011) }\end{array}$ & $\begin{array}{l}\text { There are only } 56 \text { percent } \\
\text { of the schools that modify } \\
\text { the curriculum. Moreover } \\
\text { most of the schools did not } \\
\text { have specially adapted } \\
\text { sport program, vocational } \\
\text { education program, and } \\
\text { arts program, for students } \\
\text { with disability }\end{array}$ \\
\hline 4 & Wati (2014) & $\begin{array}{l}\text { Lack of funding for the } \\
\text { implementation of } \\
\text { inclusive education, } \\
\text { including in curriculum } \\
\text { management }\end{array}$ \\
\hline 5 & $\begin{array}{l}\text { Isabella, Emosda, \& } \\
\text { Suratno (2014) }\end{array}$ & $\begin{array}{l}\text { Teachers have problem in } \\
\text { creating lesson plan }\end{array}$ \\
\hline 6 & $\begin{array}{c}\text { Yusuf, Sunardi, } \\
\text { Rachman, \& Haryono } \\
\text { (2014) }\end{array}$ & $\begin{array}{c}\text { The schools had not } \\
\text { written a manual as the } \\
\text { guidelines in } \\
\text { implementation of } \\
\text { inclusive education }\end{array}$ \\
\hline 7 & $\begin{array}{c}\text { Haryono \& Widiastuti } \\
\text { (2015) }\end{array}$ & $\begin{array}{c}\text { There is no special } \\
\text { evaluation report for } \\
\text { student with disabilities yet }\end{array}$ \\
\hline 8 & Zakia (2015) & $\begin{array}{c}\text { The role of special } \\
\text { education teachers is still } \\
\text { not optimal } \\
\text { caused by the addition } \\
\text { duties as classroom } \\
\text { teacher, } \\
\text { and career sustainability } \\
\text { for special education } \\
\text { teachers. }\end{array}$ \\
\hline 9 & Rifani (2016) & $\begin{array}{c}\text { Teacher's lack of } \\
\text { knowledge and experience } \\
\text { in implementing inclusive } \\
\text { education. }\end{array}$ \\
\hline 10 & Tarnoto (2016) & $\begin{array}{c}\text { Teacher's lack of } \\
\text { knowledge and experience } \\
\text { in implementing inclusive } \\
\text { education and giving } \\
\text { program for student with } \\
\text { disabilities. }\end{array}$ \\
\hline
\end{tabular}

Based on the results shown in table 1 , it can be concluded that several main problems in the management of the inclusive school curriculum were

1. Modifying the curriculum for student with disabilities.

2. Lack of funding for the implementation of curriculum management.
3. Availability of appropriate manual in implementation of inclusive education especially in curriculum management.

4. Lack of teacher's knowledge and experience in implementing inclusive education.

Based on problems above, special education teachers had an important role to implement inclusive school curriculum management. This could be seen from ten research result, eight of them were concerned with the special education teachers.In particular,special education teachers had problem in modify curriculum, create special evaluation report, and lack of knowledge and experience in implementing inclusive education appropriately. Those problems in special education teachers were caused by lots of factors.

First, special education teachers who can't modify curriculum and create special evaluation report can be caused by lack of knowledge and experience due to their inappropriate graduation. This is in line with Dagnew (2016) who states that most of teachers in inclusive schools are not adequately trained to deal with students with disabilities in their classes. Moreover other school members such as headmaster and classroom teachers mainly did not have appropriate knowledge and experience too. This condition make special education teachers can't fulfill their duties and responsibilities well.

This situation happened because of the limited training program and socialization in context of inclusive education implementation especially in curriculum for all teachers. As a result, many teachers are not specifically trained to manage heterogenous classes, teachers do not have adequate quality as teachers for the students with disabilities, teachers do not hold any routine discussions about giving services for the students with disabilities, the classroom teachers do not have sensitivity and proactivity to students with disabilities, and finally, the classroom teachers have a tendency on special education teachers, when they should teach students with disabilities.

Furthermore, while related to the availability of manual in implementation of inclusive education, especially in curriculum Education Department already creates General Guide of Inclusive Education Implementation in Indonesia (2011). Eventhough is still inadequate, because there is no specific steps how to modify the curriculum for students with disabilities and also what kind of program beside of learning that students which disabilities really needed.

Moreover the lack of funding for the implementation of curriculum management, it is based on each province to manage funding for inclusive education. So that province income being the key factor in funding for inclusive education, and province with low income level might have problem with funding 
So in order to cope those problems explained previously, a model for the management of the inclusive school curriculum must be created. Basically, the model for the curriculum management for the inclusive school is not far different from the school management in common which emphasizes cooperation to reach the goals of education at schools through implementing the principal management on its implementation (Hermanto, 2010:73).

Moreover Yusuf, Sunardi, Rachman, \& Haryono (2014:160) states that inclusive education management includes the process of planning, organizing, implementing, and controlling aspects of the inclusive education management involving institution, curriculum, learning process, assessments, the student interrelation, teachers, facilities, community involvement, and budgeting. Furthermore, Bubpha, Erawan, \& Saihong (2012:228) explains that model of the inclusive education management in Thailand includes three main processes, which are input, process, and output. The input process is arranging learning plans collaboratively and creatively. The process of implementation is the process of selecting, connecting, adapting, getting relevance, and testing. While the output process focuses on the graduate quality to clarify the needs, to determine the attainment, to design the working plan, and to check the activities.

Hence, based on the explanations above, the recommended model of the management of the inclusive school teachers is school-based management model which gives autonomy to schools to manage curriculum by maximizing the use of school resources. The selection of school-based management model is strengthened by Sunaryo (2009:5) who reveals the importance of utilizing and distributing the resources provided at schools to implement the inclusive education. Furthermore, Waitoller and Artiles (2013:347) explain that the success of the inclusive education is based on the school parties' works through meaningful process with the system that may develop. But also the support from the government is also needed (Wati, 2014:377). Hence, based on the analysis, the model of the school-based management for inclusive schools curriculum management is showed in the figure 2 .

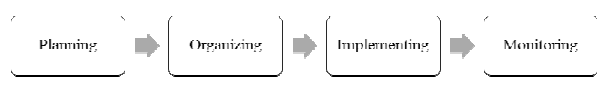

Figure 2. Process of School Based-Curriculum Management in Inclusive School
The model of school-based curriculum management for inclusive school needs to be implemented by the principals, teachers, community (including parents), as well as the government. The implementation of each management process optimally uses available resources at school within the main activities in each section as follows:

1) Planning

Planning is an activity to determine: the team to modify the curriculum, scheduling activities, and budget planning. This process needs to be conducted by principals in collaboration with teachers or education authorities if it is necessary.

2) Organizing

Organizing is the process of determining curriculum level for each students. This process is based on condition of students with disabilities in each class. This process needs to be conducted by principals in collaboration with teachers, and also needs to be discussed with parents.

3) Implementing

The main processes of school-based curriculum management for inclusive school is the implementation of plan that has already made before. In this process, teachers must do their roles, duties, and responsibilities well based on modified curriculum. And also it is really important for teachers to have routine discussion with parents or principals in terms of giving lesson and program for the students with disabilities.

4) Monitoring

Monitoring is continuous process through mutual checking between all doers to ensure that the management is done well. Especially this process can be done by principals, community (such as parents), and also government (especially education authorities).

\section{CONCLUSION}

In this research it can be concluded that There were four main problems in management of inclusive school's curriculum in Indonesia including: difficulties in modify the curriculum, lack of funding, availability of specific manual, and lack of tearcher's knowledge and experience. The problems were caused by lots of factors including unappropriate graduation, lack of training program, and government support especially in manual of inclusive education and funding. The recommended model of the management of the inclusive school curriculum is the school-based management through the following stages such as planning, organizing, implementing, and monitoring. 


\section{RECOMMENDATION}

Based on the conclusion above, it is recommended that principals, teachers, community, and government should work together by following management process properly. In detail, it can be recommended as follows:

1. It is essential that principals oversee the implementation of each teacher's duties as well as provide solutions for the implementation of curriculum management and cooperate with other relevant parties.

2. It is suggested that teachers should be able to implement curriculum for students with disabilities well through discussions and develop competencies through various activities

3. It is crucial that community especially parents should do routine monitoring activities in the implementation of curriculum management and also join inclusive school's discussions.

4. It is recommended that government do wider socialization about inclusive education manual, and also make a special allocation for teachers and curriculum implementation in inclusive schools.

\section{REFERENCES}

[1] Bubpha, Suchada, Prawit Erawan, Prasong Saihong, "Model Development for Inclusive Education Managemet:Practical Guidelines for Incusive Schools"., Journal of Education and Practice, vol 3, 2012, pp.228-229.

[2] Chimhenga, Sylod, "The Implementation of Inclusive Education for Children with Disabilities in Primary Schools:A Theoritical Probability or Practical Possibility ?, Asian Journal of Educational Research, vol 4, 2016, pp. 34.

[3] Dagnew, Asart, "Factors Affecting the Implementation of Inclusive Education in Primary Schools of Bahir Dar Town Administration", Education Research Journal, vol 3, 2013, pp. 66.

[4] Firdaus, Endis., Inclusive Education and its Implementation in Indonesia, Presented in National Seminar on Education in Universitas Jenderal Soedirman Purwokerto, 2010.

[5] Garnida, Dadang, Incusive Education, Bandung : Refika Aditama; 2015, pp. 56-57.

[6] Haryono, Ahmad Syaifudin, Sri Widiastuti, "Evaluation of Inclusive Education for Children with Special Needs in Central Java Province", Jurnal Penelitian Pendidikan, vol 32, 2015, pp.124.
[7] Hermanto, " Inclusive Education Impementation is Need Serious School Management", Jurnal Pendidikan Khusus, vol 6, 2010, pp. 73.

[8] ILO, Better Work Indonesia : Employing Persons with Disabilities. 2014, (Online), (http://betterwork.org/indonesia/wp content/uploads/20130201_Employing-Personswith Disabilities-Guideline_Indonesia_Final.pdf, downloaded 15 July 2017).

[9] Isabella, Paramita, Emosda, Suratno, "Evaluation of the Implementation of Inclusive Education for Students with Disabilities in Public Elementary School 131/IV Jambi City", Tekno-Pedagogi, vol 4, 2014, pp. 50.

[10] Mara, Daniel \& Mara, Elena-Lucia, Curriculum Adaption in Inclusive Education. ProcediaSocial and Behavioral Science, vol 46, 2012.

[11] Rifani, Latifa Garnisti, "The Evaluation of The Implementation of Inclusive Education for Children with Special Needs in Public Elementary School Bangunrejo 2 Yogyakarta", Jurnal Widia Ortodidaktika, 2016, pp. 961.

[12] Smith, J David, Inclusion : School for All Students, Bandung : Nuansa Publisher, 2015.

[13] Sunanto, Juang, Implementation of Inclusive Education in Elementary Schools, Bandung: Pusat Kajian dan Inovasi Pendidikan Sekolah Pascasarjana UPI, 2009.

[14] Sunardi, Issues and Problems on Implementation of Inclusive Education for Disable Children in Indonesia, Tsukuba: CRICED-University of Tsukuba; 2008.

[15] Sunardi, Munawir Yusuf, Gunarhadi, Priyono, John L. Yeager, "The Implementation of Inclusive Education for Students with Special Needs in Indonesia", Excellence in Higher Education, vol 2, 2011, pp. 4-5.

[16] Sunaryo, Incusive Education Management (Concept, Regulation, and Implementation on Special Education Perspectives), Bandung : Jurusan PLB FIP UPI, 2009.

[17] Tarnoto, Nissa. "The Probblems in Inclusive Elementary Schools", Humanitas, vol 13, 2016, pp. 55-56.

[18] Team, General Guide of Inclusive Education Implementation, Jakarta : Ministry of Education and Culture, 2011.

[19] Wati, Ery, "Inclusive Education Management in Public Elementary School 32 Banda Aceh City", Jurnal Ilmiah Didaktika, vol 14, pp. 377.

[20] Yusuf, Munawir, Sunardi, Maman Rachman, Haryono. (2014). The Development of Inclusive Education Management Model to Improve Principals and Teachers Performance in Elementary Schools", The Journal of Educational Development ,2, pp. 155-156,160.

[21] Zakia, Dieni Laylatul. (2015). Special Education Teachers : Pillars of Inclusive Education. Surakata : Education National Seminar Proceeding. 
